ARTICLE

DOI: $10.1038 /$ ncomms7445 OPEN

\title{
Total synthesis of clostrubin
}

Ming Yang ${ }^{1}$, Jian $\mathrm{Li}^{1} \&$ Ang $\mathrm{Li}^{1}$

Clostrubin is a potent antibiotic against methicillin- and vancomycin-resistant bacteria that was isolated from a strictly anaerobic bacterium Clostridium beijerinckii in 2014. This polyphenol possesses a fully substituted arene moiety on its pentacyclic scaffold, which poses a considerable challenge for chemical synthesis. Here we report the first total synthesis of clostrubin in nine steps (the longest linear sequence). A desymmetrization strategy is exploited based on the inherent structural feature of the natural product. Barton-Kellogg olefination forges the two segments together to form a tetrasubstituted alkene. A photoinduced $6 \pi$ electrocyclization followed by spontaneous aromatization constructs the hexasubstituted B ring at a late stage. In total, $200 \mathrm{mg}$ of clostrubin are delivered through this approach.

\footnotetext{
${ }^{1}$ State Key Laboratory of Bioorganic and Natural Products Chemistry, Collaborative Innovation Center of Chemistry for Life Sciences, Shanghai Institute of Organic Chemistry, Chinese Academy of Sciences, 345 Lingling Road, Shanghai 200032, China. Correspondence and requests for materials should be addressed to A.L. (email: ali@sioc.ac.cn).
} 
T he discovery of effective antibiotic agents is an urgent global demand for combating drug-resistant pathogenic bacterium strains ${ }^{1,2}$. Secondary metabolites that are produced by microbes as chemical defence have proven to be the most important source of such agents ${ }^{3-14}$. In May 2014, Hertweck and co-workers ${ }^{15}$ reported the isolation of clostrubin (1, Fig. 1) from the strictly anaerobic bacterium C. beijerinckii. This compound exhibits remarkable potency against methicillinresistant Staphylococcus aureus and vancomycin-resistant enterocci, with minimum inhibitory concentrations of 0.12 and $0.97 \mu \mathrm{M}$, respectively. From a structural perspective, clostrubin (1) poses considerable synthetic challenge owing to the fused aromatic ring system and multisubstitution pattern. The potential of $\mathbf{1}$ as a lead compound for antibiotic development and its limited supply from natural sources stimulated us to launch a chemical synthesis programme immediately.

In this paper, we report the first total synthesis of clostrubin (1) from commercially available starting materials. This concise synthesis (nine-step for the longest linear sequence) benefits from the inherent structural symmetry of $\mathbf{1}$. An advanced olefin intermediate was constructed through Barton-Kellogg olefination, and a $6 \pi$ electrocyclization promoted by ultraviolet light assembled the fully substituted B ring.

\section{Results}

Retrosynthetic analysis. We undertook a retrosynthetic analysis of clostrubin (1) taking advantage of the inherent symmetry ${ }^{16}$ of its molecular architecture, as illustrated in Fig. 1. The initial disassembly of the fully substituted B ring leads to a precursor 2; the recombination of the sterically hindered C8-C9 biaryl bond
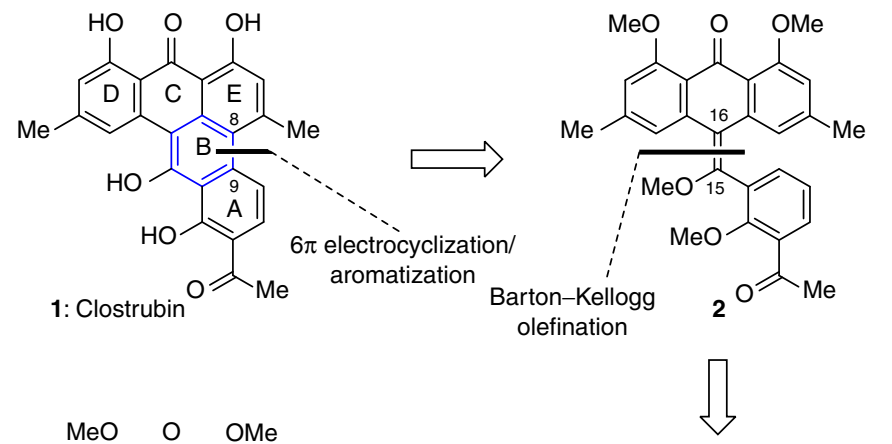<smiles>COc1cc(C)cc2c1C(=O)c1c(OC)cc(C)cc1C2[N+]#N</smiles><smiles>CCCCCC</smiles><smiles>COC(=O)c1cccc(C(C)=O)c1OC</smiles><smiles>CCCC</smiles><smiles>[R]OC(C=C([OH2+])[OH2+])=CC(=C)C</smiles><smiles>Oc1ccccc1I</smiles>

Figure 1 | Retrosynthetic analysis of clostrubin. The inherent structural symmetry of the molecule inspires a desymmetrization strategy. A BartonKellogg olefination would be used for assembling a sterically hindered tetrasubstituted olefin. A $6 \pi$ electrocyclization/aromatization sequence is envisioned as the key step for the construction of the hexasubstituted aromatic $B$ ring. could rely on a $6 \pi$ electrocyclization reaction. Electrocyclization has emerged as a powerful tool for the construction of fused ring systems since Nicolaou's pioneering synthesis of endiandric acids ${ }^{17-32}$. In particular, the strategy of $6 \pi$ electrocyclization/ aromatization has demonstrated a significant advantage in the synthesis of multisubstituted arenes ${ }^{33-44}$. Recently, we exploited such a strategy in the total syntheses of a series of natural products, such as tubingensin $\mathrm{A}$, daphenylline, xiamycin and oridamycin families, and rubriflordilactone $\mathrm{A}^{45-48}$. It should be mentioned that the construction of hexasubstituted arenes using such strategy is rare in natural product synthesis. Preparing the symmetrical, tetrasubstituted olefin $\mathbf{2}$ is indeed of significant challenge with the conventional olefination methods, and Barton-Kellogg reaction is envisioned as a suitable solution ${ }^{49-54}$. Interestingly, this olefination method has found remarkable applications in material science ${ }^{55-57}$ rather than natural product synthesis in recent years. Disconnection at the C15-C16 bond results in stabilized diazo compound 3 and thioester 4 . The former may arise from the corresponding anthraquinone precursor, which is further traced back to 2,6-dibromo-1,4benzoquinone (ref. 58) 5 and Brassard diene (refs 59,60) 6 in a double retro-Diels-Alder (D-A) manner. The latter would be accessed from commercially available iodide 7 by using lithium chemistry.

Synthesis of the two segments. The synthesis commenced with the preparation of diazoketone 3, as shown in Fig. 2. A sequence of double D-A reactions was carried out: 2,6-dibromo-1,4-benzoquinone 5, prepared in one step from commercially available $1,3,5$-tribromophenol ${ }^{58}$, reacted smoothly with an excess of diene $\mathbf{8}$ to afford anthraquinone $\mathbf{9}$ along with a small amount of mono$O$-methyl-9, presumably via the intermediacy of $\mathbf{1 0}$. The regioselectivity of the $\mathrm{D}-\mathrm{A}$ reactions may be attributable to the electronic bias induced by the bromine atom. The addition of<smiles>C=C(C)C=C(OC)OCCCC1(OC)C=C(C)CC2C(=O)C=C(Br)C(=O)C21Br</smiles><smiles>C=C(C)C=C(OC)O[CH+]CCCCC(C)(C)C</smiles>
(c) $\mathrm{SnCl}_{2}, \mathrm{HCl}$<smiles>C=C1c2c(C)cc(C)cc2C([N+]#N)c2cc(C)cc(C)c21</smiles>

Figure 2 | Synthesis of the anthraquinone segment. Reagents and conditions: (a) tetrahydrofuran (THF), $-78^{\circ} \mathrm{C}, 6 \mathrm{~h}$; then silica gel, $22^{\circ} \mathrm{C}$, 2 h. (b) $\mathrm{K}_{2} \mathrm{CO}_{3}$ (3.0 eq), Mel (2.5 eq), N,N-dimethylformamide (DMF), $22{ }^{\circ} \mathrm{C}, 18 \mathrm{~h}, 45 \%$ (two steps). (c) $\mathrm{SnCl}_{2} \bullet \mathrm{H}_{2} \mathrm{O}$ (6.0 eq), aqueous $\mathrm{HCl}$ (37 wt\%), $\mathrm{AcOH}, 22^{\circ} \mathrm{C}, 30 \mathrm{~min}$. (d) $\mathrm{DBU}$ (3.0 eq), $\mathrm{TsN}_{3}$ (1.1 eq), methylene chloride $\left(\mathrm{CH}_{2} \mathrm{Cl}_{2}\right), 22{ }^{\circ} \mathrm{C}, 20 \mathrm{~h}, 89 \%$ (two steps). TMS, trimethylsilyl. 
silica gel may accelerate the hydrolysis of the silyl ether and thus led to a rapid aromatization along with release of $\mathrm{HBr}$. Notably, when a single equivalent of $\mathbf{8}$ was used for the D-A reaction, a bromonaphthoquinone was readily prepared, presumably with the intermediacy of a mono cycloadduct ${ }^{61}$. The crude 9 was treated with $\mathrm{K}_{2} \mathrm{CO}_{3}$ and $\mathrm{MeI}$ to give compound 11 (45\% overall yield from 5). 11 underwent Clemmensen-type reduction in the presence of $\mathrm{SnCl}_{2}$ and $\mathrm{HCl}$ to give the corresponding monoketone ${ }^{62}$, which instantaneously tautomerized to anthranol 12. Exposure of crude 12 to 1,8-diazabicyclo[5.4.0] undec-7-ene (DBU) and $\mathrm{TsN}_{3}$ furnished diazoketone 3 in $89 \%$ overall yield.

We observed unexpected reactivity of anthraquinone 11 (Fig. 3) during the above studies, which influenced the overall strategy of the synthesis. In theory, the C9 carbonyl of $\mathbf{1 1}$ should be sterically more hindered for nucleophilic attack due to two neighbouring methoxy groups. From an electronic perspective, this upper ketone could be considered as an equivalent of a double vinylogous carbonate than is also rather unreactive as an electrophile. To our surprise, we obtained hydrazone 13 in $61 \%$ yield when treating $\mathbf{1 1}$ with $\mathrm{TsNHNH}_{2}$; the anticipated regioisomer was not detected. The structure of $\mathbf{1 3}$ was determined by X-ray crystallographic analysis. This observation interrupted our initial plan of exploiting the C10 tosylhydrazone of $\mathbf{1 1}$ as the potential precursor for the Barton-Kellogg olefination. We further examined other types of nucleophiles such as benzyl Grignard reagent for the addition reaction with 11. In this case, two regioisomeric alcohols $\mathbf{1 4}$ and $\mathbf{1 5}$ were isolated in 32\% and $40 \%$ yields, respectively. Both structures were confirmed by nuclear Overhauser effect (NOE) studies. The enhanced reactivity of the C9 carbonyl may be attributable to inductive effects from the $o$-methoxy substitutents or relief of 1,3-allylic strain that occurs on nucleophilic additions. Thus, the strategy involving direct olefination of C10 carbonyl of anthraquinone 11 (for example, with functionalized benzylic metal species or phosphonate carbanion) had to be abandoned due to the poor regioselectivity.

We then focused on the synthesis of the thioester segment as the electron donor in the devised Barton-Kellogg olefination, as shown in Fig. 4. Aldehyde $\mathbf{1 6}$ was prepared in one step from commercially available 2-iodophenol ${ }^{63}$. Treatment with $\mathrm{K}_{2} \mathrm{CO}_{3}$ and MeI gave methyl ether 17 (99\% yield), which underwent $\mathrm{MeMgBr}$ addition followed by silylation to provide compound $\mathbf{1 8}$

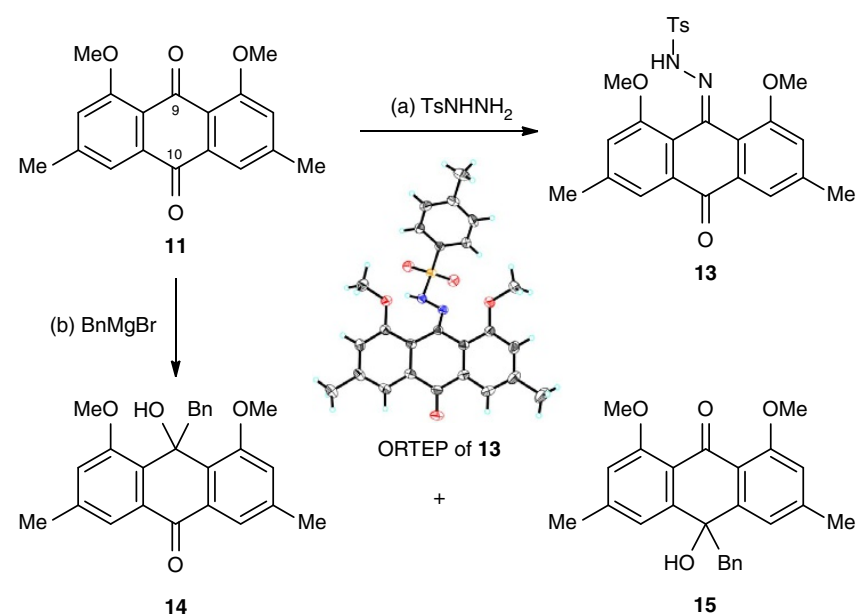

Figure 3 | Unusual reactivity of the anthraquinone intermediate.

Reagents and conditions: (a) $\mathrm{TsNHNH}_{2}$ (1.0 eq), $\mathrm{TsOH} \bullet \mathrm{H}_{2} \mathrm{O}$ (10 mol\%), $\mathrm{EtOH}, 60^{\circ} \mathrm{C}, 2 \mathrm{~h}, 61 \%$. (b) $\mathrm{BnMgBr}(1.0 \mathrm{eq})$, tetrahydrofuran (THF), $22{ }^{\circ} \mathrm{C}, 15 \mathrm{~min}, 32 \%$ for $\mathbf{1 4}$ and $40 \%$ for $\mathbf{1 5}$. ORTEP, Oak Ridge Thermal Ellipsoid Plot.
(94\% yield) in one pot. Hexamethylphosphoramide (HMPA) was found to be crucial to enhance the nucleophilicity of the magnesium alkoxide. $\mathbf{1 8}$ was subjected to the magnesiumhalogen exchange conditions (EtMgBr) to generate a functionalized Grignard reagent ${ }^{45,47,64-66}$, which was quenched by $\mathrm{CS}_{2}$ and MeI to give dithioester 19. It is noteworthy that lithium-halogen exchange did not lead to a satisfactory result. The desilylation took place spontaneously during acid workup to deliver alcohol 20 in $67 \%$ yield from 18. Oxidation of 20 with Dess-Martin periodinane (DMP) afforded ketone $21(83 \%$ yield) without destroying the sulfur-containing functionalities, and the subsequent methanolysis furnished thioester 4 in $66 \%$ yield.

Completion of the synthesis. With both fragments in hand, we directed our attention to the construction of the aromatic B ring, as depicted in Fig. 5. It is well documented in the literature of Barton-Kellogg olefination that thioketones readily react with diazo compounds without promoters or catalysts ${ }^{55-57}$. After examination of the conventional conditions, we realized that the stabilized diazoketone 3 needed to be activated by $\mathrm{Rh}_{2}(\mathrm{OAc})_{4}$ to form the metal-carbenoid intermediate ${ }^{52,54,67-70}$, which was further trapped by relatively unreactive thioester 4 . The<smiles>Oc1ccccc1I</smiles>

7<smiles>COc1c(I)cccc1C(C)OC</smiles>

18<smiles>COC(=O)c1cccc(C(C)=O)c1OC</smiles>

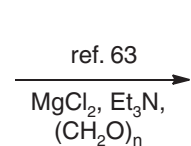

$\left(\mathrm{CH}_{2} \mathrm{O}\right)_{n}$

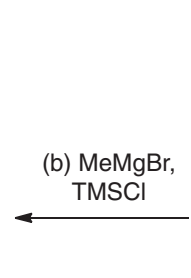

(a) $\mathrm{K}_{2} \mathrm{CO}_{3}, \mathrm{Mel}$<smiles>COc1c(I)cccc1C=O</smiles>

17 (c) EtMgBr,
$\mathrm{CS}_{2}, \mathrm{Mel}$<smiles>COC(=S)c1cccc(C(C)OC)c1OC</smiles>

19

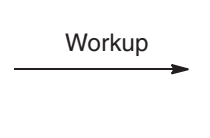

(e) $\mathrm{MeONa}$<smiles>COc1c(C(C)=S)cccc1C(C)O</smiles>

20<smiles>Cc1ccccc1</smiles><smiles>COc1c(C(C)=O)cccc1C(C)=S</smiles>

21

Figure 4 | Synthesis of the thioester segment. Reagents and conditions: (a) $\mathrm{K}_{2} \mathrm{CO}_{3}$ (1.5 eq), Mel (1.5 eq), $\mathrm{N}, \mathrm{N}$-dimethylformamide (DMF), $22^{\circ} \mathrm{C}$, $20 \mathrm{~h}, 99 \%$. (b) $\mathrm{MeMgBr}(1.05 \mathrm{eq}), 0{ }^{\circ} \mathrm{C}, 10 \mathrm{~min}$; then HMPA (2.0 eq), triethylamine $\left(\mathrm{Et}_{3} \mathrm{~N} ; 1.5 \mathrm{eq}\right)$, chlorotrimethylsilane $(\mathrm{TMSCl} ; .5 \mathrm{eq})$, tetrahydrofuran (THF), $22^{\circ} \mathrm{C}, 10 \mathrm{~min}, 94 \%$. (c) $\mathrm{EtMgBr}(1.5 \mathrm{eq}), \mathrm{THF}, 50^{\circ} \mathrm{C}$, $1 \mathrm{~h}$; then $\mathrm{CS}_{2}(30 \mathrm{eq}), 70^{\circ} \mathrm{C}, 3 \mathrm{~h}$; then $\mathrm{Mel}(4.0 \mathrm{eq}), 22^{\circ} \mathrm{C}, 8 \mathrm{~h}, 67 \%$.

(d) DMP (1.2 eq), methylene chloride $\left(\mathrm{CH}_{2} \mathrm{Cl}_{2}\right), 22^{\circ} \mathrm{C}, 1 \mathrm{~min}, 83 \%$.

(e) $\mathrm{MeONa}(10.0 \mathrm{eq})$, methanol $(\mathrm{MeOH}), 50^{\circ} \mathrm{C}, 4 \mathrm{~h}, 66 \%$. 


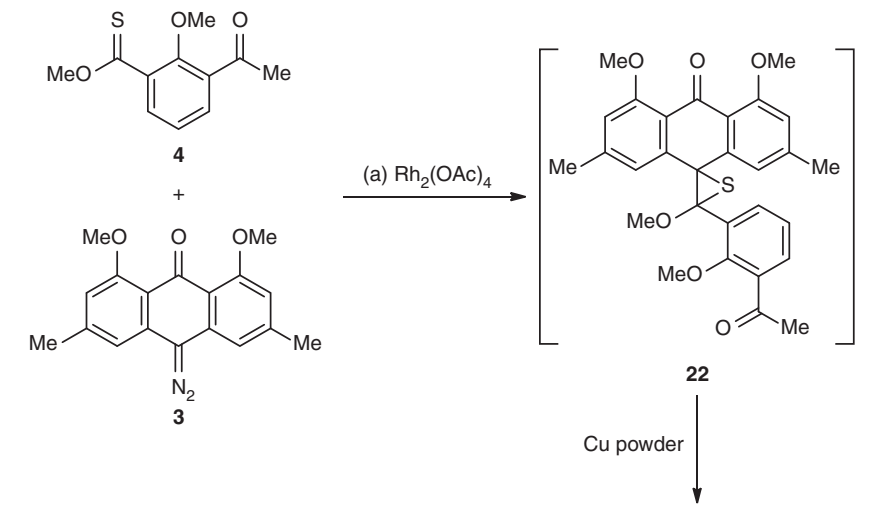

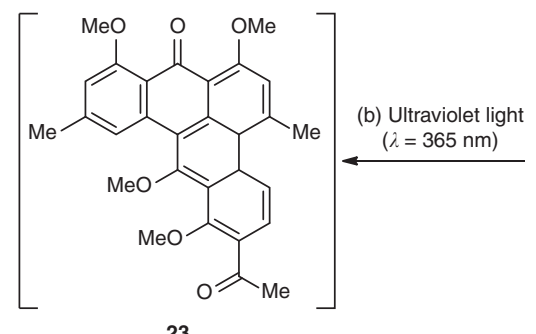<smiles></smiles>

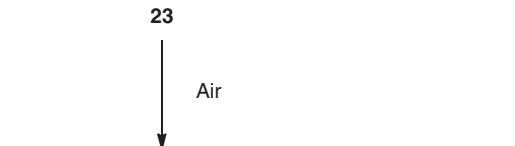<smiles>COc1cc(C)cc2c1C(=O)c1c(O)c(C)cc(OC)c1C2=O</smiles><smiles>CC(=O)c1ccc2c(c1O)c(O)c1c3c(c(O)cc(C)c32)C(=O)c2c(O)cc(C)cc2-1</smiles>

Figure $\mathbf{5}$ | Completion of the synthesis of clostrubin. Reagents and conditions: (a) $\mathrm{Rh}_{2}(\mathrm{OAc})_{4}\left(5 \mathrm{~mol} \%\right.$ ), toluene, $50^{\circ} \mathrm{C}, 55 \mathrm{~min}$; then $\mathrm{Cu}$ powder, $110^{\circ} \mathrm{C}, 1.5 \mathrm{~h}, 85 \%$. (b) ultraviolet light ( $\lambda=365 \mathrm{~nm}, \mathrm{Hg}$ lamp), $\mathrm{CHCl}_{3}, 22^{\circ} \mathrm{C}, 8 \mathrm{~h}, 55 \%$. (c) aq. $\mathrm{HBr}(48 \mathrm{wt} \%), \mathrm{AcOH}, 120^{\circ} \mathrm{C}, 10 \mathrm{~h}, 95 \%$.

postulated episulfide intermediate $\mathbf{2 2}$ was reduced by $\mathrm{Cu}$ powder in situ to afford tetrasubstituted olefin $\mathbf{2}$ in $85 \%$ overall yield. We examined a series of conditions such as heating or $\mathrm{FeCl}_{3}$ to promote the last $\mathrm{C}-\mathrm{C}$ bond formation but only observed decomposition. Inspired by our synthesis of daphenylline ${ }^{46}$, we irradiated 2 with ultraviolet light $(\lambda=365 \mathrm{~nm})$. To our delight, this symmetrical olefin underwent a $6 \pi$ electrocyclization, presumably to provide pentacyclic intermediate $\mathbf{2 3}$, which was spontaneously oxidized under an air atmosphere during workup to furnish tetramethyl clostrubin $\mathbf{2 4}$ (55\% yield from 2). Global deprotection of the methyl groups with aqueous $\mathrm{HBr}$ (48 wt\%) gave clostrubin (1) with excellent efficiency. The spectra and physical properties of the synthetic $\mathbf{1}$ are consistent with those reported for the natural product. In total, $200 \mathrm{mg}$ of 1 were obtained through the synthesis.

\section{Discussion}

In summary, we have accomplished the first total synthesis of clostrubin. The concise and efficient route took advantage of the $6 \pi$ electrocyclization strategy as well as the inherent structural symmetry of the molecule. The synthesis provides a practical means to obtain this potent antibiotic for further investigations, considering the limited supply and difficult isolation of the naturally occurring sample.

\section{Methods}

General. All reactions were carried out under an argon atmosphere with dry solvents under anhydrous conditions, unless otherwise noted. Tetrahydrofuran was distilled immediately before use from sodium-benzophenone ketyl. Methylene chloride, $N, N$-dimethylformamide, triethylamine, $N, N$-diisopropylethylamine and chlorotrimethylsilane were distilled from calcium hydride and stored under an argon atmosphere. Methanol was distilled from magnesium and stored under an argon atmosphere. Reagents were purchased at the highest commercial quality and used without further purification, unless otherwise stated. Solvents for chromatography were used as supplied by Titan Chemical. Reactions were monitored by thin-layer chromatography carried out on S-2 $0.25 \mathrm{~mm}$ E. Merck silica gel plates (60F-254) using ultraviolet light as visualizing agent and aqueous ammonium cerium nitrate/ammonium molybdate or basic aqueous potassium permanganate as developing agent. E. Merck silica gel (60, particle size $0.040-0.063 \mathrm{~mm}$ ) was used for flash column chromatography. Preparative thin-layer chromatography separations were carried out on 0.25 or $0.50 \mathrm{~mm}$ E. Merck silica gel plates (60F254). Nuclear magnetic resonance (NMR) spectra were recorded on Bruker AV400 or Agilent 500/54/ASP instrument and calibrated by using residual undeuterated chloroform $\left(\delta_{\mathrm{H}}=7.26\right.$ p.p.m. $)$ and $\mathrm{CDCl}_{3}\left(\delta_{\mathrm{C}}=77.16\right.$ p.p.m. $)$ or undeuterated dimethylsulfoxide $\left(\delta_{\mathrm{H}}=2.50\right.$ p.p.m. $)$ and dimethylsulfoxide-d ${ }_{6}\left(\delta_{\mathrm{C}}=39.52\right.$ p.p.m.), as internal references. Infrared spectra were recorded on a Thermo Scientific Nicolet 380 FT-IR spectrometer. Melting points are uncorrected and were recorded on a Shanghai Jingke SGW X-4 apparatus. High-resolution mass spectra were recorded on a Bruker APEXIII 7.0 Tesla ESI-FT or a Waters Micromass GCT Premier EI mass spectrometer.

For ${ }^{1} \mathrm{H}$ and ${ }^{13} \mathrm{C}$ NMR spectra of compounds, see Supplementary Figs 1-26. For heteronuclear multiple quantum correlation spectroscopy (HMQC) and heteronuclear multiple-bond correlation spectroscopy (HMBC) spectra of compound 13, see Supplementary Figs 27 and 28. For nuclear Overhauser effect spectroscopy (NOESY) spectra of compound 14 and 15, see Supplementary Figs 29 and 30 . For the comparisons of ${ }^{1} \mathrm{H}$ and ${ }^{13} \mathrm{C}$ NMR spectra of the natural and synthetic clostrubin, see Supplementary Figs 31 and 32. For the comparisons of ${ }^{1} \mathrm{H}$ and ${ }^{13} \mathrm{C}$ NMR spectroscopic data of the natural and synthetic clostrubin, see Supplementary Tables 1 and 2. For the experimental procedures and spectroscopic and physical data of compounds and the crystallographic data of compound 13, see Supplementary Methods.

\section{References}

1. Pearson, H. 'Superbug' hurdles key drug barrier. Nature 418, 469-469 (2002).

2. Laxminarayan, R. et al. Antibiotic resistance-the need for global solutions Lancet Infect. Dis. 13, 1057-1058 (2013).

3. Clardy, J., Fischbach, M. A. \& Walsh, C. T. New antibiotics from bacterial natural products. Nat. Biotechnol. 24, 1541-1550 (2006).

4. Fischbach, M. A. \& Walsh, C. T. Antibiotics for emerging pathogens. Science 325, 1089-1093 (2009).

5. Häbich, D. \& von Nussbaum, F. Platensimycin, a new antibiotic and "superbug challenger" from nature. ChemMedChem 1, 951-954 (2006).

6. Nicolaou, K. C., Li, A. \& Edmonds, D. J. Total synthesis of platensimycin. Angew. Chem. Int. Ed. 45, 7086-7090 (2006).

7. Nicolaou, K. C., Tria, G. S. \& Edmonds, D. J. Total synthesis of platencin. Angew. Chem. Int. Ed. 47, 1780-1783 (2008).

8. Tiefenbacher, K. \& Mulzer, J. Synthesis of platensimycin. Angew. Chem. Int. Ed. 47, 2548-2555 (2008).

9. Walker, S. et al. Chemistry and biology of ramoplanin: a lipoglycodepsipeptide with potent antibiotic activity. Chem. Rev. 105, 449-476 (2005).

10. James, R. C., Pierce, J. G., Okano, A., Xie, J. \& Boger, D. L. Redesign of glycopeptide antibiotics: back to the future. ACS Chem. Biol. 7, 797-804 (2012).

11. von Nussbaum, F. et al. Structure and total synthesis of lysobactin (katanosin B). Angew. Chem. Int. Ed. 46, 2039-2042 (2007).

12. Tan, Y. X. \& Romesberg, F. E. Latent antibiotics and the potential of the arylomycins for broad-spectrum antibacterial activity. Med. Chem. Commun. 3, 916-925 (2012).

13. Lam, H. Y. et al. Total synthesis of daptomycin by cyclization via a chemoselective serine ligation. J. Am. Chem. Soc. 135, 6272-6279 (2013).

14. King, A. M. et al. Aspergillomarasmine A overcomes metallo- $\beta$-lactamase antibiotic resistance. Nature 510, 503-506 (2014).

15. Pidot, S., Ishida, K., Cyrulies, M. \& Hertweck, C. Discovery of clostrubin, an exceptional polyphenolic polyketide antibiotic from a strictly anaerobic bacterium. Angew. Chem. Int. Ed. 53, 7856-7859 (2014).

16. Anderson, R. J. \& Morris, J. C. Total synthesis of variolin B. Tetrahedron Lett. 42, 8697-8699 (2001).

17. Nicolaou, K. C., Petasis, N. A., Zipkin, R. E. \& Uenishi, J. The endiandric acid cascade. Electrocyclizations in organic synthesis. 1. Stepwise, stereocontrolled 
total synthesis of endiandric acids A and B. J. Am. Chem. Soc. 104, 5555-5557 (1982).

18. Nicolaou, K. C., Petasis, N. A., Uenishi, J. \& Zipkin, R. E. The endiandric acid cascade. Electrocyclizations in organic synthesis. 2. Stepwise, stereocontrolled total synthesis of endiandric acids C-G. J. Am. Chem. Soc. 104, 5557-5558 (1982).

19. Nicolaou, K. C., Zipkin, R. E. \& Petasis, N. A. The endiandric acid cascade. Electrocyclizations in organic synthesis. 3. "Biomimetic" approach to endiandric acids A-G. Synthesis of precursors. J. Am. Chem. Soc. 104, 5558-5560 (1982).

20. Nicolaou, K. C., Petasis, N. A. \& Zipkin, R. E. The endiandric acid cascade. Electrocyclizations in organic synthesis. 4. Biomimetic approach to endiandric acids A-G. Total synthesis and thermal studies. J. Am. Chem. Soc. 104, 5560-5562 (1982).

21. Beaudry, C. M., Malerich, J. P. \& Trauner, D. Biosynthetic and biomimetic electrocyclizations. Chem. Rev. 105, 4757-4778 (2005).

22. Sklenicka, H. M. et al. Stereoselective formal [3+3] cycloaddition approach to cis-1-azadecalins and synthesis of (-)-4a,8a-diepi-pumiliotoxin C. Evidence for the first highly stereoselective $6 \pi$-electron electrocyclic ring closures of 1 azatrienes. J. Am. Chem. Soc. 124, 10435-10442 (2002).

23. Li, C., Johnson, R. P. \& Porco, J. A. Total synthesis of the quinone epoxide dimer ( + )-torreyanic acid: application of a biomimetic oxidation/ electrocyclization/Diels-Alder dimerization cascade. J. Am. Chem. Soc. 125, 5095-5106 (2003).

24. Parker, K. A. \& Lim, Y.-H. The Total synthesis of (-)-SNF4435 C and (+)SNF4435 D. J. Am. Chem. Soc. 126, 15968-15969 (2004).

25. Miller, A. K. \& Trauner, D. Mining the tetraene manifold: total synthesis of complex pyrones from Placobranchus ocellatus. Angew. Chem. Int. Ed. 44, 4602-4606 (2005).

26. Volgraf, M. et al. Biomimetic synthesis of the IDO inhibitors exiguamine A and B. Nat. Chem. Biol. 4, 535-537 (2008).

27. Chaumontet, M., Piccardi, R. \& Baudoin, O. Synthesis of 3,4-dihydroisoquinolines by a $\mathrm{C}\left(\mathrm{sp}^{3}\right)-\mathrm{H}$ activation/electrocyclization strategy: total synthesis of coralydine. Angew. Chem. Int. Ed. 48, 179-182 (2009).

28. Sloman, D. L., Bacon, J. W. \& Porco, J. A. Total synthesis and absolute stereochemical assignment of kibdelone C. J. Am. Chem. Soc. 133, 9952-9955 (2011).

29. Sharma, P., Ritson, D. J., Burnley, J. \& Moses, J. E. A synthetic approach to kingianin A based on biosynthetic speculation. Chem. Commun. 47, 10605-10607 (2011)

30. Barcan, G. A., Patel, A., Houk, K. N. \& Kwon, O. A torquoselective $6 \pi$ electrocyclization approach to reserpine alkaloids. Org. Lett. 14, 5388-5391 (2012)

31. Drew, S. L., Lawrence, A. L. \& Sherburn, M. S. Total synthesis of kingianins A, D, and F. Angew. Chem. Int. Ed. 52, 4221-4224 (2013).

32. Lim, H. N. \& Parker, K. A. Total synthesis of kingianin A. Org. Lett. 15, 398-401 (2013)

33. Anderson, E. A., Alexanian, E. J. \& Sorensen, E. J. Synthesis of the furanosteroidal antibiotic viridin. Angew. Chem. Int. Ed. 43, 1998-2001 (2004).

34. Ohmori, K. et al. Concise total synthesis and structure assignment of TAN1085. Angew. Chem. Int. Ed. 43, 3167-3171 (2004).

35. Harrowven, D. C., Pascoe, D. D., Demurtas, D. \& Bourne, H. O. Total synthesis of (-)-colombiasin A and (-)-elisapterosin B. Angew. Chem. Int. Ed. 44, 1221-1222 (2005)

36. Fürstner, A., Domostoj, M. M. \& Scheiper, B. Total synthesis of dictyodendrin B. J. Am. Chem. Soc. 127, 11620-11621 (2005).

37. Greshock, T. J. \& Funk, R. L. Synthesis of indoles via $6 \pi$-electrocyclic ring closures of trienecarbamates. J. Am. Chem. Soc. 128, 4946-4947 (2006).

38. Greshock, T. J. \& Funk, R. L. An approach to the total synthesis of welwistatin. Org. Lett. 8, 2643-2645 (2006).

39. Huntley, R. J. \& Funk, R. L. Total syntheses of ( \pm )-cis-trikentrin A and ( \pm )cis-trikentrin B via electrocyclic ring closures of 2,3-divinylpyrrolines. Org. Lett. 8, 3403-3406 (2006)

40. Huntley, R. J. \& Funk, R. L. A Strategy for the total synthesis of dragmacidin E. Construction of the core ring system. Org. Lett. 8, 4775-4778 (2006).

41. Staben, S. T. et al. Gold(I)-catalyzed cyclizations of silyl enol ethers: application to the synthesis of (+)-lycopladine A. Angew. Chem. Int. Ed. 45, 5991-5994 (2006).

42. Sloman, D. L., Mitasev, B., Scully, S. S., Beutler, J. A. \& Porco, J. A. Synthesis and biological evaluation of ABCD ring fragments of the kibdelones. Angew. Chem. Int. Ed. 50, 2511-2515 (2011).

43. Lu, Z., Yang, M., Chen, P., Xiong, X. \& Li, A. Total synthesis of hapalindoletype natural products. Angew. Chem. Int. Ed. 53, 13840-13844 (2014).

44. Xiong, X. et al. Synthesis of indole terpenoid mimics via a functionalitytolerated $\mathrm{Eu}(\mathrm{fod}) 3$-catalyzed conjugate addition. Chem. Asian J. doi:10.1002/ asia.201403312.

45. Bian, M. et al. Total syntheses of anominine and tubingensin A. J. Am. Chem. Soc. 134, 8078-8081 (2012)
46. Lu, Z., Li, Y., Deng, J. \& Li, A. Total synthesis of the Daphniphyllum alkaloid daphenylline. Nat. Chem. 5, 679-684 (2013).

47. Meng, Z. et al. Total synthesis and antiviral activity of indolosesquiterpenoids from the xiamycin and oridamycin families. Nat. Commun. 6, 6096 (2015).

48. Li, J., Yang, P., Yao, M., Deng, J. \& Li, A. Total synthesis of rubriflordilactone A. J. Am. Chem. Soc. 136, 16477-16480 (2014).

49. Staudinger, H. \& Siegwart, J. Einwirkungen von aliphatischen diazoverbindungen auf thioketone. Helv. Chim. Acta 3, 833-840 (1920).

50. Barton, D. H. R. \& Willis, B. J. Olefin synthesis by twofold extrusion processes. J. Chem. Soc. D 1225-1226 (1970).

51. Kellogg, R. M. \& Wassenaar, S. Thiocarbonyl ylides. An approach to "tetravalent sulfur" compounds. Tetrahedron Lett. 11, 1987-1990 (1970).

52. Kim, G., Chu-Moyer, M. Y. \& Danishefsky, S. J. The total synthesis of dl-indolizomycin. J. Am. Chem. Soc. 112, 2003-2005 (1990).

53. Honda, T. et al. A synthesis of $(+)$-nonactic acid by means of the sulfur-ylide rearrangement. Tetrahedron 48, 79-88 (1992).

54. Kim, G., Chu-Moyer, M. Y., Danishefsky, S. J. \& Schulte, G. K. The total synthesis of indolizomycin. J. Am. Chem. Soc. 115, 30-39 (1993).

55. Feringa, B. L. In control of motion: from molecular switches to molecular motors. Acc. Chem. Res. 34, 504-513 (2001).

56. Plunkett, K. N. et al. Expeditious synthesis of contorted hexabenzocoronenes. Org. Lett. 11, 2225-2228 (2009).

57. Zhang, X. et al. Synthesis, self-assembly, and charge transporting property of contorted tetrabenzocoronenes. J. Org. Chem. 75, 8069-8077 (2010).

58. Omura, K. Rapid conversion of phenols to $p$-benzoquinones under acidic conditions with lead dioxide. Synthesis (Mass). 1145-1148 (1998).

59. Fleming, I., Goldhill, J. \& Paterson, I. $\gamma$-Sulphenylation of $\alpha \beta$-unsaturated aldehydes, ketones, and esters: the use of $O$-silylated dienolates. Tetrahedron Lett. 20, 3205-3208 (1979).

60. Savard, J. \& Brassard, P. Regiospecific syntheses of quinones using vinylketene acetals derived from unsaturated esters. Tetrahedron Lett. 20, 4911-4914 (1979).

61. Bringmann, G. et al. A convergent total synthesis of the michellamines. J. Org Chem. 63, 1090-1097 (1998).

62. Prinz, H., Burgemeister, T., Wiegrebe, W. \& Müller, K. Syntheses of anthracenones. 2. Preparation of 1,8-dimethoxy-(dimethylanthralin) and 4,5dihydroxy-9(10H)-anthracenone (isoanthralin): a revision. J. Org. Chem. 61, 2857-2860 (1996).

63. Brady, R. M. et al. Synthesis of conformationally constrained benzoylureas as $\mathrm{BH}_{3}$-mimetics. Org. Biomol. Chem. 10, 5230-5237 (2012).

64. Tamborski, C. \& Moore, G. J. Synthesis of polyfluoroaromatic magnesium compounds through the exchange reaction. J. Organomet. Chem. 26, 153-156 (1971).

65. Furukawa, N., Shibutani, T. \& Fujihara, H. Preparation of pyridyl Grignard reagents and cross coupling reactions with sulfoxides bearing azaheterocycles. Tetrahedron Lett. 28, 5845-5848 (1987).

66. Knochel, P. et al. Highly functionalized organomagnesium reagents prepared through halogen-metal exchange. Angew. Chem. Int. Ed. 42, 4302 (2003).

67. Takano, S., Tomita, S., Takahashi, M. \& Ogasawara, K. Condensation of a chiral tetrahydro-2-furanthione with diazocarbonyl compounds. Synthesis (Mass). 1116-1117 (1987)

68. Padwa, A., Kinder, F. R. \& Zhi, L. Generaton of thiocarbonyl ylides from the rhodium(II)-catalyzed cyclization of diazothiocarbonyl compounds. Synlett 287-288 (1991).

69. Hürzeler, M., Bernet, B., Mäder, T. \& Vasella, A. Glyconothio-O-lactones part II. cycloaddition to dienes, diazomethane, and carbenoids. Helv. Chim. Acta 76, 1779-1801 (1993).

70. Mlostón, G. \& Heimgartner, H. Carbenoid reactions of dimethyl diazomalonate with aromatic thioketones and 1,3-thiazole-5(4H)-thiones. Helv. Chim. Acta 79, 1785-1792 (1996).

\section{Acknowledgements}

This paper is dedicated to Professor Yong-Qiang Tu for his mentorship to M.Y and J.L. We thank Professor Christian Hertweck for helpful discussions. Financial support was provided by Ministry of Science and Technology (2013CB836900), National Natural Science Foundation of China (21290180, 21172235 and 21222202), Pujiang Program (12PJ1410800) and China Postdoctoral Science Foundation (2014M551480, to M.Y.)

\section{Author contributions}

A.L., M.Y. and J.L. conceived the synthetic route; A.L. directed the project; M.Y. and J.L. conducted the work; A.L., M.Y. and J.L. analysed the results; and A.L. wrote the manuscript.

\section{Additional information}

Accession codes: The X-ray crystallographic coordinates for structure (13) reported in this article have been deposited at the Cambridge Crystallographic Data Centre (CCDC) under deposition number CCDC 1028256. These data can be obtained free of charge 
from The Cambridge Crystallographic Data Centre via www.ccdc.cam.ac.uk/data request/cif.

Supplementary Information accompanies this paper at http://www.nature.com/ naturecommunications

Competing financial interests: The authors declare no competing financial interests.

Reprints and permission information is available online at http://npg.nature.com/ reprintsandpermissions/
How to cite this article: Yang, M. et al. Total synthesis of clostrubin. Nat. Commun. 6:6445 doi: 10.1038/ncomms7445 (2015).

(c) (i) This work is licensed under a Creative Commons Attribution 4.0 International License. The images or other third party material in this article are included in the article's Creative Commons license, unless indicated otherwise in the credit line; if the material is not included under the Creative Commons license, users will need to obtain permission from the license holder to reproduce the material. To view a copy of this license, visit http://creativecommons.org/licenses/by/4.0/ 